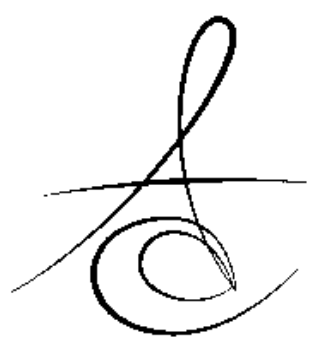

\title{
A PATIENT WITH EPIDERMAL CYST IN MANDIBULA, SIMULTANEOUSLY ENUCLEATION OF EPIDERMAL CYST AND IMPLANT PLACEMENT: A CASE REPORT \#
}

\section{ALT ÇENESİNDE EPİDERMAL KİST BULUNAN BİR HASTADA KİSTİN ALINMASI VE EŞ ZAMANLI OLARAK İMPLANT YERLEŞTİRİLMESİ: BİR OLGU SUNUMU}

\author{
Arş. Gör. Dt. Mithat TERZí \\ Arş. Gör. Dt. Fatih KARAASLAN* \\ Yrd. Doç. Dr. Muhammet ÇALIK ${ }^{* *}$ \\ Doç. Dr. Alparslan DİLSİz* \\ Uzm. Dr. Eren ALTUN**
}

Makale Kodu/Article code: 1577

Makale Gönderilme tarihi: 13.03.2014

Kabul Tarihi; $\quad 04.04 .2014$

\section{ABSTRACT}

Dermoid cysts are malformations that rarely seen in oral mucosa and can be defined as an epidermoid when lining presents only epithelium. Epidermoid and dermoid cysts are rarely seen in intraosseous and there was a few report about their presentation in the jaws. The development in implant surfaces and surgical techniques has led to changes in treatment protocol such as immediate implant placement. Immediate implant placement has some advantages such as, reduction in the time of treatment and number of surgical interventions. We aimed to present a case about an epidermoid cyst in mandible which treated by enucleation and simultaneously immediate implant replaced. In radiographic examination, an asymptomatic, properly limited lesion was performed in the lower left premolar region of 46year-old male patient. Under local anesthesia, the lesion was enucleated and dental implant was performed with using membrane-graft. Clinical and radiographical controls was performed for 4 months and osseointegration achieved successfully. Enucleation and placing implant in the same session has been reduced number and duration of treatment.

Key Words: Dental implants, epidermoid cyst, osseointegration.

\section{GİRİ̧̧}

Dermoid cysts are bening cystic lesions and histologically can be classified epidermoid, dermoid or teratoid. They can occur anywhere in the body, $\% 7$ of they may be found in head and neck. ${ }^{1,2}$ Only $1.6 \%$ of

\section{ÖZET}

Dermoid kistler oral mukozada nadir görülen, yalnızca epitelde görüldüklerinde epidermoid kist olarak adlandırılan malformasyonlardır. Epidermoid ve dermoid kistler kemik içerisinde nadir olarak görülürler ve sadece birkaç olguda çene kemiklerinde görüldüğü rapor edilmiştir. İmplant yüzey özellikleri ve cerrahi tekniklerdeki gelişmeler immediat implant tedavisine olanak sağlamaktadır. İmmediat implant yerleştirmenin tedavi süresini ve cerrahi müdahale sayısını azaltma gibi avantajları vardır. Bu olguda, mandibuladaki epidermoid kistin enükleasyonunu ve immediat implant yerleştirilmesini sunmayı amaçladık. 46 yaşındaki erkek hastada yapılan radyografik muayenede sol alt premolar bölgesinde sınıları düzgün asemptomatik bir lezyona rastlandı. Lokal anestezi altında lezyon enukle edildi ve ilgili bölgeye geft-membran da kullanılarak dental implant uygulandı. 4 ay boyunca klinik ve radyografik takibi yapıldı ve osseintegrasyonun başarılı bir şekilde sağlandığı görüldü. Aynı seansta lezyonun enuklasyonu ve implantın yerleştirilmesi ile cerrahi müdahale sayısı ve tedavi süresi azaltıldı.

Anahtar Kelimeler: Diş implantları, epidermoid kist, kemikle bütünleşim.

these involves floor of mouth and tongue. We know that a few epidermoid cysts in the jaws was reported. These cysts occur second or third decade of life. Clinically, cysts present as a slow growing and asymptomatic mass.

*Atatürk Üniversitesi Diş Hekimliği Fakültesi Periodontoloji AD.

**Atatürk Üniversitesi Tıp Fakültesi Patoloji AD.

\# Bu olgu Europerio7 kongresinde poster olarak sunulmuştur. 6-9 June 2012 Wien, Austria. 
Dental implant therapy is considered as a predictable and reliable treatment option for replacing missing teeth and is now believed to be a fundamental treatment procedure with a high success rate. Several authors have proposed that the immediate implant placement reduces bone resorption and minimizes the time of treatment. Immediate implant placement has similar success compared to deferred basis implant placement. Today immediate implant placement is a very predictable treatment with very high success rate. $^{3}$

In this case, we reported a patient with epidermoid cyst in mandible, and cyst was enucleated and immediate implant was placed.

\section{CASE REPORT}

A 45-year-old, partial edentulous male patient was admitted to the Department of Periodontology, Faculty of Dentistry at Atatürk University. In medical history, there was no systemic illness, infectious diseases and drug allergy. In dental history, patient had difficulty to eat because of tooth loss. Swelling and redness weren't seen in oral mucosa, and he had no pain. In the orthopantomograph radiography, it was detected that a well circumscribed lesion was existed at the left of mandible.

Under local anesthesia, flap was removed, cyst had been reached, cyst was enucleated. Dental implant was placed at the same location, bone graft (Bio-Oss $®$, Geistlich Sons Ltd. Wolhusen, Switzerland) and collagene membrane (Collagene AT $®$, Dentreal, Italy) were used. Removed piece was sent to pathology laboratory. The patient was prescribed antibiotics (amoxicillin and clavulanate potassium 1000 $\mathrm{mg}$, every 12 hours, for 5 days), analgesics (etodolac $400 \mathrm{mg}$, every 12 hours, for 7 days) and instructed to rinse twice daily with $0.12 \%$ chlorhexidine oral rinse for a week. Histopathologic findings showed that the lesion was epidermoid cyst which includes keratinous material in the cyst lumen that lined by stratified squamous epithelium.

Enuclation of epidermoid cyst and implant placement in the same session is first case report in literature clinical and radiographical controls was performed for 4 months and osseointegration achieved successfully. The post-operative healing was uneventful and there was no pain, redness, swelling and edema. There was no pathological condition in alveolar bone.

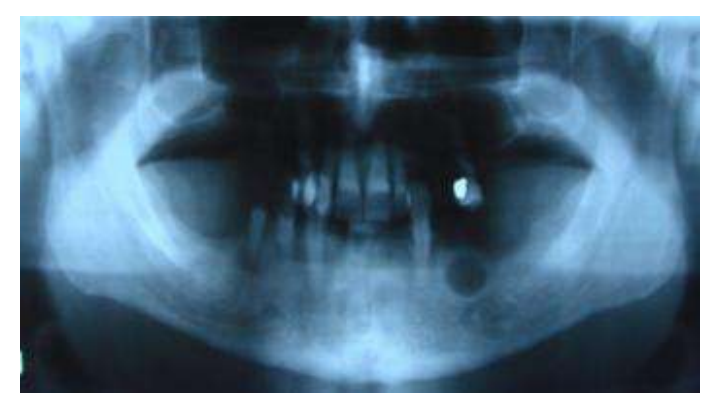

Figure 1. Radiography taken before operation

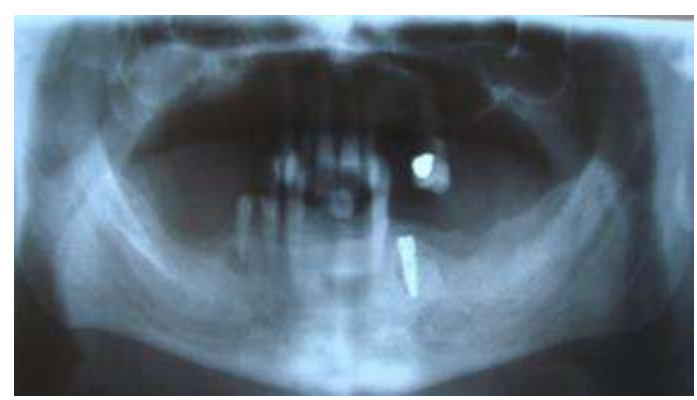

Figure 2. Radiography taken after operation

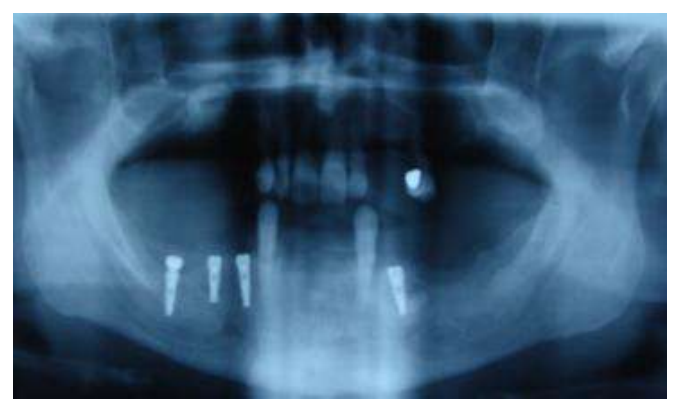

Figure 3. Radiography taken 2 weeks after operation

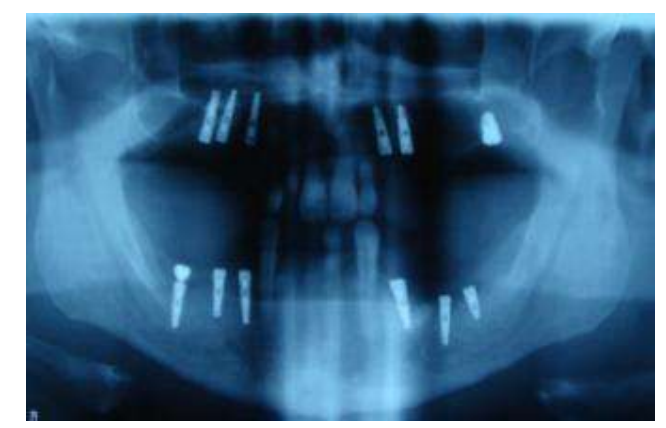

Figure 4. Radiography taken 4 mounths after operation

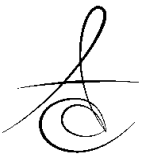


Atatürk Üniv. Diş Hek. Fak. Derg.

J Dent Fac Atatürk Uni

Supplement: 9, Yıl: 2014, Sayfa : 6-9

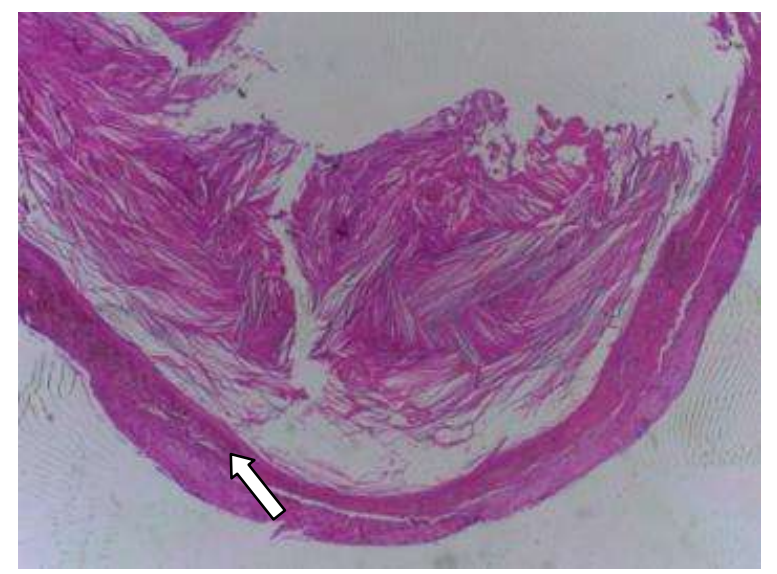

Figure 5. Histopathologic image indicating keratinous material in the cyst lumen $(x 25, H \& E)$

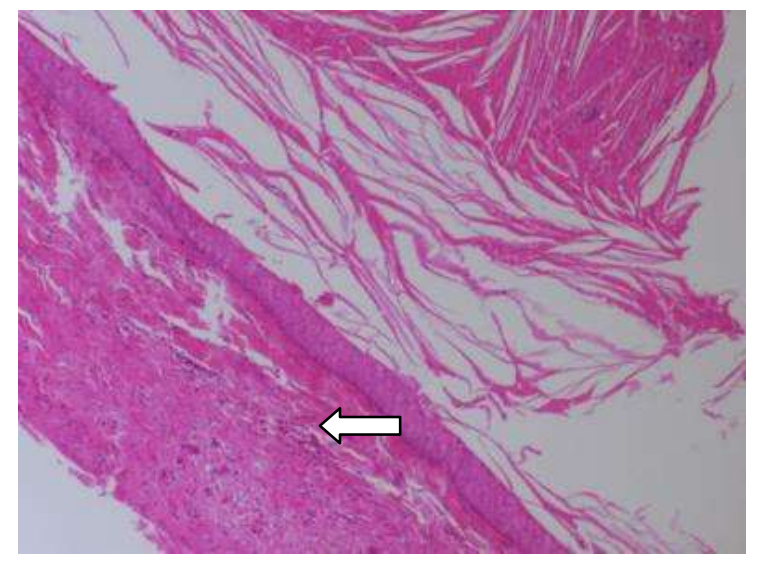

Figure 6. Histopathological image of stratified squamous epithelium lining the cyst lumen

\section{DISCUSSION}

Epidermoid cysts present asymptomatic, painless, slowly growing and well-circumscribed swellings. They usually involve soft tissues and their intraosseous presentation is rare. Epidermoid cysts can be classified into congenital or acquired. Epidermoid cysts develop by traumatic implantation of epithelial cells into deeper tissues because of accident or previous surgical events. A latent period follows the trauma, during the healing, implanted epithelial cells multiply and produce a small mass of keratin. We hypothesised that in our patient the epithelial cells from oral mucosa migrate along the mandible and proliferated around it. This resulted in formation of an epidermal cyst communicated with the traumatic extraction.
TERZİ, KARAASLAN, ÇAKIR, DİLSİZ, ALTUN

In most cases epidermoid cysts are treated by enucleation and it is the best way of prevent recurrence. ${ }^{4-6}$ Surgical procedure changes according to size and position of cyst. During the surgery, intraepidermal layer shoul be removed to prevent recurrense. In our case, we use enucleation procedure under local anesthesia. Marsupialization is a alternative treatment for giant cysts. ${ }^{4}$

Immediate implant placement in a socket with presence of infection is contraindicated because of being a risk for osseointegration. ${ }^{7,8}$ Some studies suggested that a periapical pathology could be a predisposing factor for peri-implant diseases and implant failure. ${ }^{9,10}$ The pathology can be a potential risk for initial phase of bone healing and this affects osseointegration process. Novaes et al. ${ }^{11}$ made a histomorphometric study in dogs and he didn't find any about difference osseointegration level of immediate implants in fresh sockets with infectious ones. Crespi et al. ${ }^{12}$ investigated marginal bone level in immediate implants with or without history of infection. They didn't find any difference. Immediate implant placement after extraction of teeth with presence of radiolucent periapical images was studied. In this studies, after the granulation was removed, socket was irrigated with sterile saline. In this procedure, there was no postoperative complication and implant was achieved a good primer stability. ${ }^{13,14}$ Although various studies have shown that osseointegration in such areas is difficult to obtain, osseointegration has successfully occurred in our study. These results show that osseointegration could occur on a surface previously contaminated with cyst membrane.

There is some disagreement in use of antibiotic before and after implant treatment in presence of radiolucent periapical pathology. Lindeboom et al. ${ }^{15}$ And Siegenthaler et al. ${ }^{14}$ use preoperative antibiotics (Clindamycin $600 \mathrm{mg}$ one hour before surgery). Casap et al. ${ }^{16}$ suggested preoperative using daily dose of 1.5 mg amoxicillin four days to surgery and continuing to use same dosage for ten days after surgery. VillaRangert ${ }^{17}$ and Siegenthaler et al. ${ }^{14}$ recommended use of postoperative antibiotics with no consensus. In our study we prescribed antibiotics (amoxicillin and clavulanate potassium $1000 \mathrm{mg}$, every 12 hours, for 5 days), analgesics (etodolac $400 \mathrm{mg}$, every 12 hours, for 7 days) and instructed to rinse twice daily with $0.12 \%$ chlorhexidine oral rinse for a week. 
Some authors affirmed that placement of immediate implant with using graft and membrane had some risks; such as graft or membrane exposure, partial or total loss of graft, non osseointegration of immediate implant. ${ }^{18,19}$ In our study there was no complication like this.

In such cases implants can be replaced after cyst was enucleated. Therefore immediate implant placement reduces surgical interventions and minimizes the time of treatment.

\section{REFERENCES}

1. Koca H, Seckin T, Sipahi A, Kazanc A. Epidermoid Cyst in the Floor of the Mouth: Report of a Case. Quintessence Int 2007;38:473-7.

2. Ozan F, Polat HB, Ay S, Goze F. Epidermoid Cyst of the Buccal Mucosa: A Case Report. J Contemp Dent Pract 2007;3:90-6.

3. Chen ST, Wilson TG, Hämmerle $\mathrm{CH}$. Immediate or Early Placement of Implants Following Tooth Extraction: Review of Biologic Basis, Clinical Procedures, and Outcomes. Int J Oral Maxillofac Implants 2004;19 Suppl:12-25.

4. Yilmaz I, Yilmazer C, Yavuz H, Bal N, Ozluoglu LN. Giant Sublingual Epidermoid Cyst: A Report of Two Cases. J Laryngol Otol 2006; 120: 19.

5. Zuber TJ. Minimal excision technique for epidermoid (sebaceous) cyst. Am Fam Physician 2002 Apr 1;65:1409-20.

6. Cuscheri A, Steele RJC, Moossa AR. Disorders of Skin and Soft Tissues. Essential Surgical Practice. 4th ed. London: Arnold, 2002:46.

7. Schwartz-Arad D, Chaushu G. The Ways and Wherefores of Immediate Placement of Implants into Fresh Extraction Sites: A Literature Review. J Periodontol 1997;68:915-23.

8. Uzun G, Keyf F. Surface Characteristics of the Implant Systems and Osseointegration. Atatürk Üniv Diş Hek Fak Derg 2007; Suppl 2:43-50

9. Ayangco L, Sheridan PJ. Development and Treatment of Retrograde Peri-İmplantitis İnvolving a Site with a History of Failed Endodontic and Apicoectomy Procedures: A Series of Reports. Int J Oral Maxillofac Implants 2001;16:412-7

10. Karoussis IK, Salvi GE, Heitz-Mayfield LJA, Brägger $\mathrm{U}$, Hämmerle CHF, Lang NP. Long-Term Implant Prognosis in Patients with and Without a History of
Chronic Periodontitis: A 10-Year Prospective Cohort Study of the ITI Dental Implant System. Clin Oral Implants Res 2003;14:329-39.

11. Novaes $A B$, Vidigal Júnior $G M$, Novaes $A B$, Grisi $M F$, Polloni $S$, Rosa $A$. Immediate Implants Placed into İnfected Sites: A Histomorphometric Study in Dogs. Int J Oral Maxillofac Imp 1998;13:422-7.

12. Crespi $R$, Capparè $P$, Gherlone E. Fresh-Socket Implants in Periapical İnfected Sites in Humans. J Periodontol 2010;81:378-83.

13. Villa R, Rangert B. Immediate and Early Function of Implants Placed in Extraction Sockets of Maxillary Infected Teeth: A Pilot Study. J Prosthet Dent 2007;97 Suppl 6:96-108.

14. Siegenthaler DW, Jung RE, Holderegger $C$, Roos $M$, Hämmerle $\mathrm{CH}$. Replacement of Teeth Exhibiting Periapical Pathology by Immediate Implants: A Prospective, Controlled Clinical Trial. Clin Oral Implants Res 2007;18:727-37.

15. Lindeboom JA, Tjiook $Y$, Kroon FH. Immediate Placement of Implants in Periapical Infected Sites: A Prospective Randomized Study in 50 Patients. Oral Surg Oral Med Oral Pathol Oral Radiol Endod 2006;101:705-10.

16. Casap N, Zeltser C, Wexler A, Tarazi E, Zeltser R. Immediate Placement of Dental Implants into Debrided Infected Dentoalveolar Sockets. J Oral Maxillofac Surg 2007;65:384-92.

17. Villa R, Rangert B. Early Loading of Interforaminal Implants Immediately Installed After Extraction of Teeth Presenting Endodontic and Periodontal Lesions. Clin Implant Dent Relat Res 2005;7 Suppl 1:S28-35.

18. Triplett RG, Schow SR. Autologous Bone Grafts and Endosseous İmplants: Complementary Techniques. J Oral Maxillofac Surg 1996;54:48694.

19. Raghoebar GM, Schoen P, Meijer HJ, Stellingsma $K$, Vissink A. Early Loading of Endosseous Implants in the Augmented Maxilla: A 1-Year Prospective Study. Clin Oral Implants Res 2003;14:697-702
Yazışma Adresi
Dr. Mithat Terzi
Atatürk Üniversitesi Diş Hekimliği Fakültesi
Periodontoloji AD.
Gsm: 05324051358
e- mail: drmtht@hotmail.com 
Atatürk Üniv. Diş Hek. Fak. Derg.

J Dent Fac Atatürk Uni

TERZİ, KARAASLAN, ÇAKIR,

Supplement: 9, Yıl: 2014, Sayfa : 6-9

DİLSİZ, ALTUN 